\title{
Evaluation of the Educational Drama as an Innovative Method to be Adopted by Teachers in Order to Enhance Critical Thinking Skills of Students in Primary School
}

\author{
Aikaterini Dima, Eleni Kaiafa \& Asterios Tsiaras \\ University of Peloponnese, Nauplio, GREECE \\ Faculty of Fine Arts, Department of Theatre Studies
}

Received: 31 May 2020 • Accepted: 14 August 2020 - Published Online: 19 October 2020

\begin{abstract}
The aim of this study is to examine and determine the extent to which educational drama, as an innovative teaching approach, can cultivate critical thinking of students in primary school. Based on the principles of educational drama, 15 theatrical workshops were designed in relation with and corresponding to the culture and interests of the specific age group. The experimental method that was followed, was designed and implemented in three discrete stages including: the pre-research stage, the main research stage and the results extraction stage. The sample comprising 400 students aged 8-10 has been drawn from six different primary schools in Greece, the subjects of which were randomly selected. Five critical thinking skills were studied, including subtraction, induction, observation, reliability, detection and troubleshooting skills. The qualitative and quantitative data collected was next triangulated in order to lead to the desired result. The results confirmed the main research hypothesis, hence educational drama, as an innovative method, can enhance students' critical thinking in primary school.
\end{abstract}

Keywords: educational drama, critical thinking, skills, innovative method, primary school students.

\section{Introduction}

In the $21^{\text {st }}$ century teachers are required to adapt to contemporary data of the times and modernize the teaching methods that they apply in the classroom. Huss (2019) suggests that it is important for teachers to work together in order to be able to acquire and develop the necessary skills. It is considered to be important to enrich their teaching approaches and evaluate their work so that they constantly become better through the experiences that they gain.

Children and young people are at the core of this need for change as in the future it will be they who will be called upon to judge what needs to be changed in society and one way to do that is to learn how to think efficiently and effectively. According to Facione and Facione (2013) if you teach people how to make the right decisions and equip themselves with the right skills, they will in turn improve their future and become active members of society. Teaching a student to think critically may not guarantee a life full of happiness, but it certainly offers them the foundations for better route of progress in all areas and is clearly better than burdening them with the heavy load of bad consequences of their poor decisions and choices.

(C) Authors. Terms and conditions of Creative Commons Attribution 4.0 International (CC BY 4.0) apply. Correspondence: Aikaterini Dima, University of Peloponnese, Faculty of Fine Arts, Department of Theatre Studies, Nauplio, GREECE. E-mail: kathrin.dima@yahoo.gr. 
A. Dima, E. Kaiafa \& A. Tsiaras - Evaluation of the Educational Drama as an Innovative Method...

- Educational drama as an innovative method for teachers.

- An intervention program was designed and implemented based on the principles of educational drama with the aim of cultivating critical thinking.

- Five critical thinking skills were studied, including subtraction, induction, observation, reliability, detection and troubleshooting skills.

- Triangulation of qualitative and quantitative data to draw reliable conclusions.

- The results of the research revealed that educational drama can cultivate critical thinking in primary school students.

In addition, according to Bailin, Case, Coombs and Daniels's theory (1999) critical thinking in school may include teaching students the value of truth-telling, making students rational and open-minded towards new stimuli, respecting their interlocutors, and being willing to think and view things through a different prism. Therefore, it is necessary to cultivate critical thinking in students. It is reasonable to ask whether critical thinking can be measured, since it is not defined according to certain rules or in a particular context.

Mc Peck (1981) argues that critical thinking is a skill that can be taught like many others but is not included in any curriculum as a subject, therefore the teacher is called upon to incorporate it in the teaching of other subjects. Landy and Montgomery (2012) consider drama in education as a significantly useful tool for students' social reform. The experience of educational drama could shape attitudes and lead to pathways of critical thought.

Neelands (2011) suggests that drama in education can develop skills that are necessary for life in modern society and include: self-discipline, teamwork, critical thinking, problem-solving ability, self-esteem and self-confidence. Bailin (1998) explores critical thinking and drama in education and concludes that students through drama enter the process of developing their own critical challenges, answering questions, stimulating their thinking and developing healthy dialogue with peers, in an atmosphere of mutual trust and respect.

In this article we are called to investigate whether educational drama can bring about this change that the education system needs and how critical thinking can be integrated into it. Educational drama is called, as an innovative method, to function as the tool that will strengthen critical thinking in the context of primary school curricula.

\section{Theoretical background}

\subsection{Drama education}

The need for modernization of pedagogical methods and learning is increasing in an era dominated by the rapid pace of communication, information and technology. However, the need for an alternative form of learning began as early as the second half of the 19th century when the arts began to be introduced into European school curricula (Kamens \& Cha, 1992). Art, therefore, is established as a means of cultivating spiritual, social, and moral values with the main goal of shaping children in depth, but the interesting thing is that it is not the value of the arts themselves that matters, but the artistic practices they use for the purpose sharpening their spirit and virtues of children (Jörissen et al., 2018). It should be noted at this point that of all the arts, the present article focuses on educational drama.

From a semantics point of view, the word "drama" means action and although as a term has been adopted by other European countries in a variety of forms such as "drame" (France) or "Schauspiel" (Germany), everywhere the term denotes theatrical or dramatic work (Pavis \& Ubersfeld, 2006). The first signs of the beginning of drama being adopted in education and in the 
classroom, appear in Plato's work “The Republic”, referring to the contribution that play should have in classes (Bolton, 2007). In mid-1960s, actors, directors and writers in Britain encouraged teenagers to engage in theater, confirming that drama in education has its roots in theater (Sextou, 2004). However, it should be argued that the combination of theater and education appears earlier in Britain in the 1920s, where the term "dramatization" was coined by Finlay Johnson (1911).

Today, however, despite the passage of time and the need for technology within the school, educational drama remains almost unchanged (Anderson, 2012), that is, it uses techniques such as play through which students can express themselves freely and spontaneously (Boal et al., 2008). It can be realized that drama has offered many benefits to the education which will specified and discussed below. "Drama is the paint that turns life into an art and builds the bridge between what this world is and what it might be" (Prentki \& Stinson, 2016: 4).

Additionally, the drama uses a symbolic language, through which the real world can be represented (Varriour, 1994). We find that drama in education, in addition to the entertaining character that it undoubtedly has, since it has a playful form at its base, also acquires a social character. It also motivates children and adults to use not only their body but their spirit and emotion (Kalidas, 2013) giving the drama a multi-layered role. However, drama in education not only offers aesthetic experience but also motivates students and drives them to learn in a different way, that is, to break away from the traditional methods they have learned so far by making it an educational phenomenon (Sextou, 2004). Cattanach (1996) also states that the most important thing offered through educational drama is the so called "aesthetic illusion", which means that educational drama and its tools, such as improvisation, games, etc., offer individual students the opportunity to simulate daily life activities in a "safe" environment created by the theatrical context without any restrictions and fears. Winship (1954) refers to the educational theater supporting that through it students have the opportunity to learn about the principles that govern, democracy and their interrelationship. In other words, through the resulting collaborations, students are trained through harmonious participation, in expressing their opinion freely and in cultivating a critical view of the world.

\subsection{Critical thinking skills}

On the basis of the above, a reasonable question that arises is related to the kind of benefit that educational drama can provide to school curricula and in the cultivation of critical thinking.

The search for the definition of critical thinking, both theoretically and empirically (through the investigation of appropriate tests), has been going on for decades without any clear definition found. Ennis, one of the theorists who has thoroughly researched critical thinking, defines it as "a reasonable reflective process focusing on deciding what to believe or do" (Ennis, 2018: 166). Nevertheless, this is apparently a definition that needs further investigation and clarification (Kuhn, 2019).

Another interesting definition that has been formulated, specifies critical thinking as an activity of the person evaluating or composing information using observation, experience, and/or communication as a guide for those who believe or act (Scriven, 1987). However, the author of this paper believes that a universally accepted definition may not exist or cannot be found since critical thinking is a conceptually complex entity involving a wide variety of skills, five basic and 35 subcategories, each one of which, according to the American Philosophical Association (APA) (Schmaltz, Jansen \& Wenckowski, 2017), need a separate definition.

In the field of education, things are complicated since critical thinking concerns most if not all of the scientific disciplines and is tangible in many categories. What dominates and is 
A. Dima, E. Kaiafa \& A. Tsiaras - Evaluation of the Educational Drama as an Innovative Method...

primarily cultivated at all levels of education primarily comprises the skills of understanding and evaluation, followed by analysis and synthesis (Kennedy, Fisher \& Ennis, 1991).

Ennis (1989) considers it beneficial for elementary school students to be taught or rather guided through the pathways of critical thinking, especially starting from the early school years. Its teaching can be initiated through a "general approach", which can take for example the form of a simple disagreement in the classroom until students are trained to think critically and develop this ability to the wider external social environment. Therefore, the importance of cultivating critical thinking in primary school students' minds can be considered as of paramount significance since besides enhancing their academic performance, it can assist students' adaptability to society in their adulthood as well.

As Marin and Halpern (2011) also confirm through their research findings, critical thinking is composed of a series of vital skills. Cultivating these critical thinking skills in education is very important since we are going through an era where information is being transmitted at a very fast pace. Essential and effective education presupposes the promotion of all of the students' critical thinking-related skills (Facione \& Facione, 1996). However, despite the unanimously acknowledged need for all school curricula to incorporate critical thinking, the literature on critical thinking cultivation and development is rather incomplete.

In the light of the above, it is deemed necessary to strengthen the critical thinking of primary school students. Skills that could be studied and measured according to Ennis (1989) include observation, reliability, induction, subtraction, problem identification and coping.

It was considered ideal in this case to use the experience of educational drama as the means that will cultivate critical thinking skills. Educational drama has the potential to turn learning into experience. Through role-playing games and theatrical improvisations, it has the potential to create a happy and creative atmosphere where students' interaction, collaborations and skills are enhanced.

\section{Methodology}

\subsection{Research objectives}

According to the theoretical framework, no one can dispute the fact that educational drama follows a dynamically evolutionary track, since it has been established as a fundamental process in human experience (Tsiaras, 2016a). As Heathcote (1984) argues, educational drama is a process in which students express themselves as they would in real life (Adigüzel, 2009: 86). The relationship between educational drama and critical thinking is based on the fact that educational drama, as an innovative tool, can cultivate and contribute to the development of the five (5) main skills of critical thinking which, as mentioned above, include observation, inductive and subtraction, reliability, detection and troubleshooting.

Observation is one of the most important skills in critical thinking. Being an observant student means that all the data of the problem can be identified and thus a correct solution can be faster found and specified. Abstraction is the ability of the student to think logically, connect and interrelate data in the right sequence and make the right decision. Inductive thinking leads students from a given data to reasonable and sound generalization and consequently to the right solution. Identifying the student's problem is also important. Examining the data of the difficult situation will lead him to deal with it. Finally, self-confidence and therefore proper control of the data source has to do with the student's perception. When the student can evaluate and ensure the reliability of a specific data source, this in turn can lead to the correct solution of the problem.

In the light of the above, the research question examined of this paper can be specified as follows: 
To what extent can educational drama, as an innovative tool, influence and enhance the critical thinking of primary school children?

In order to provide an answer to this question, an intervention program was designed and implemented based on the principles of educational drama that could cultivate these five critical thinking skills (observation, inductive and subtraction, reliability, detection and troubleshooting.)

\subsection{Pre-research preparation}

At the pre-research stage, the theoretical framework governing critical thinking and the theories around it were studied in depth. The principles of educational drama were also discussed and the steps required to be taken for the implementation of the present research were planned.

Scientific research is a continuous investigation of hypothetical propositions about the possible relationships between natural phenomena (Kerlinger, 1979). In that sense, for the selection of the methodological approach to be applied and in order for the goal and objectives of this paper to be satisfied, both the theoretical background of the research approaches and two basic criteria were taken into account. The first criterion implies that the approach to be chosen and applied has to be the one that provides the greatest possible certainty about the actual descriptive characteristics while according to the second criterion the greatest possible certainty about the true nature of the relationship between the variables has to be ensured.

It was therefore considered as vitally necessary by both the research supervisor and the members of the research team to design and implement the experimental method (Kolaczyk, 2009).

As dependent variables were identified the five critical thinking skills while as the independent variable has been decided to be the educational drama. Four hundred (400) students from six various primary schools in Greece, aged 8 to 10, were randomly selected. Two hundred students (200) were selected to compose the experimental group while the remaining two hundred (200) students compose the control group of the research. As far as the composition of the experimental group in terms of sex, 118 were girls and the remaining 82 were boys. This sample is considered to be representative of the population under examination since it was randomly chosen so as to cover the different educational and social criteria of the student population of the country's primary schools.

Then, after the theoretical framework through the review of domestic and international bibliography was established by the researchers, the fifteen (15) theatrical workshops that would be used as interventions in cultivating the critical thinking skills of primary school students were designed in detail.

The aim of these theatrical workshops was to achieve the development of students' critical thinking through playful activities and dilemmatic situations designed to lead them ultimately to the right decision. The design of each theatrical workshop was structured in such a way so that all of the six critical thinking skills could be progressively developed and enhanced.

Theatrical workshops had about the same structure. They began by telling a story in which the hero faced some obstacles and dilemmas and students were asked to help him overcoming them. This was followed by various theatrical techniques such as confidence games, role-playing games, icy images (Bolton, 2007) closed and completed with reflection. In the theatrical workshops, each student expressed their opinion after first identifying the problem, evaluating the data and the reliability of the sources, listening to everyone's opinions and leading to the correct treatment and solution of the problem. 
A. Dima, E. Kaiafa \& A. Tsiaras - Evaluation of the Educational Drama as an Innovative Method...

At the stage of preparation to be led to the main research, the questionnaire that would be given to the students before the implementation of the theatrical workshops and after their completion was designed. The research team evaluated critical thinking as a complex function based on the Cornell Class-Reasoning Test scale (Form X), a series of Cornell Critical thinking tests by Ennis, Gardiner, Morrow, Paulus and Ringel (1964) and the Starkey's Questionnaire (2010).

The questions chosen to be used were translated with the reverse translation approach (translation- back translation), modified to match the age of the sample, as well as the culture and interests of the specific age group. After checking its validity, reliability and functionality, the skills of observation, reliability, detection, troubleshooting, induction and removal were investigated at the main research stage.

The questions in the final questionnaire were in the form of multiple choice and the correct answer was always one of the four choices provided (a, b, c, d). The questionnaire consists of twenty-four (24) questions that focus on the five axes of critical thinking skills. An indicative example from the questionnaire includes the following:

You hear on TV that all buses, subways, trains, etc. will go on strike because employees are demanding an increase in their salaries. What conclusion do you draw?

(a) They have made everything more expensive so they are asking for an increase.

(b) If they are not given an increase, the ticket will be increased in the following days.

(c) People who move with these means will have to find another way of commuting and reach their business.

(d) Their bosses will not like this at all.

In addition to the questionnaire, each member of the research team was asked to keep a research diary (Burgess, 1981) to record all the important events and behaviors of the students during the implementation of the theatrical workshops.

Finally, after obtaining the required permits from the Ministry of Education and the consent of both the principals of the primary schools and the parents or the guardians of the students, the research team proceeded to the main research stage.

\subsection{The main research}

The main research phase began with the completion of the questionnaire from all 400 students. After completion the questionnaires were collected, the research team proceeded with the implementation of the 15 theatrical workshops. Each theatrical workshop for each class took place once a week and lasted 45 minutes, which is one teaching hour of the school. Theatrical workshops were held within the school schedule and during the Theatrical Education course. The 15 theatrical workshops were conducted on a sample of 200 students, which was our experimental group. This intervention lasted 4 months.

During the theatrical workshops, each researcher kept a diary, which would later be used to extract qualitative features of the research.

After the end of the 15 theatrical workshops, the research team gave for the second time the questionnaire that had been given before the intervention of the theatrical workshops. The same questionnaire was completed again by the 400 students, both in the experimental group and in the control group, to test whether the educational drama, as an innovative method, worked in cultivating critical thinking skills. 


\subsection{Example of a theatrical lab}

The following is an example of a theatrical workshop conducted as part of the research.

The theatrical workshop began with kinetic exercises and were next followed by the narration of the story. This particular story deals with a historical event, the Battle of Thermopylae, which was in the textbooks of the History of the $4^{\text {th }}$ grade of the students.

The story began somewhat like this: "The new king of Persia, Xerxes, began to prepare a new campaign against Greece. The Greeks held a meeting in the Isthmus of Corinth and decided that they should face the Persians together. The Spartans would be the leaders ...”

The children are divided into groups and are represented with an icy image, imagining the meeting at the Isthmus of Corinth.

The narration continued “... the great Persian army started in the spring of $489 \mathrm{BC}$. Never before have people seen so many armies. The Persians, after crossing the Hellespont, moved to Greece. The Greek army, led by the king of Sparta, Leonidas, headed for Thermopylae. In this narrow passage, 7,000 Greeks lined up to stop the Persians.”

The children are divided into groups and each group writes on a piece of paper, two objects that the Greek soldiers may have had with them and express their psychological state.

The story continued: “... Xerxes, when he arrived at Thermopylae, asked the Greeks to surrender their weapons. Leonidas' answer was: "Molon lave" (come and get them). And the battle began ..."

The children sitting in a circle and taking turns express in one word how they would characterize Leonidas.

"The Persians could not fight together in the strait. Those who tried to cross fell dead. Xerxes was puzzled and believed that no one would have the courage to fight. He then called on his generals and a group of military representatives to listen to them and better assess the situation."

The children are divided into two groups. The 1st group, the generals, argue that they should not surrender their weapons and leave. The $2^{\text {nd }}$ group, the representatives of the soldiers, claim that they must leave the Strait of Thermopylae. The views of each group are formulated with arguments in order to convince him and are announced to the researcher who is in the role of Xerxes.

The children sit in a circle again and each one playing the role of Xerxes announces her/his decision. What would they do in Xerxes' place?

“... Xerxes did not manage to decide what to do, but then a local from Trachina, Nightmare, who knew the surrounding mountainous area, came to him. So he approached Xerxes and promised to lead the Persians down a narrow and steep path behind Leonidas' army. Thus, those who would follow him could surround the Greeks and kill them with great ease. As soon as the king heard this, he jumped for joy and gave rich gifts to Nightmare."

The researcher selects a student who wishes to enter the role of the traitor called Nightmare and sit in the hot chair. The children below him ask questions to understand what a person he is, what he has experienced, how he feels now and what led him to this action of betrayal his Greek compatriots.

“... After that, Xerxes sent twenty thousand men with him against the Greeks at night. In the Persian army, however, there was also someone from Kimi, who was called Tyraskada, a good and right man. So at night he broke out of the Persian camp and went to Leonidas and told 
A. Dima, E. Kaiafa \& A. Tsiaras - Evaluation of the Educational Drama as an Innovative Method...

him the news, he was not aware of. Leonidas realized that his army would be surrounded and trapped."

The children form "a corridor of consciousness" as it is called where they say out loudly their thoughts about what to do and the psychological state in which Leonidas finds himself. The researcher or a child in the role of Leonidas passes through.

The narration ends “... Leonidas then told those who wanted to leave. This left 700 Thespians and 300 Spartans. The Greeks were forced to fight on two fronts. And they were all killed. However, their death went down in history as proof of great patriotism.”

Then the children themselves, regardless of what happened in the story, express their stating whether they would do the same or not, justifying each option.

\section{Results}

After collecting the completed questionnaires as well as the information written down in the research diary that were recorded during the 15 theatrical workshops, the evaluation of the research results followed. The research process was completed by triangulating the data.

The statistical processing of the values of the dependent variables in this study was observation, reliability, abstract and inductive thinking, problem identification and coping, using the SPSS statistical program. It was deemed necessary to study each dependent variable separately.

The averages of the dependent variables were measured on the same scale, at two different times, with the statistical criterion t-student. The statistical test for normal distribution was done with the Shapiro-Wilk test and the distribution of the population from which our sample comes is approximately normal.

The Cronbach's alpha reliability index was used to calculate the reliability of the measurement tool. Analyzing the results, based on the values observed before and after the intervention, Cronbach's alpha values for each of the five skills were calculated. The process was done for both the control and the experimental group.

Table 1 shows the mean estimate and standard deviation for all of the five factors as they evolved in the experimental group.

Table 1. Measurement values of the factors of variables subtraction-induction-reliabilityobservation-problem identification and troubleshooting of the experimental group

\begin{tabular}{|c|c|c|c|c|c|c|c|c|}
\hline & \multicolumn{2}{|c|}{ Before } & \multicolumn{2}{|c|}{ After } & \multicolumn{4}{|c|}{ Result } \\
\hline & $\begin{array}{c}\text { Mean } \\
\text { estimate }\end{array}$ & $\begin{array}{l}\text { standard } \\
\text { deviation }\end{array}$ & $\begin{array}{c}\text { mean } \\
\text { estimate }\end{array}$ & $\begin{array}{l}\text { standard } \\
\text { deviation }\end{array}$ & $\begin{array}{l}\text { mean } \\
\text { estimate }\end{array}$ & $\begin{array}{l}\text { standard } \\
\text { deviation }\end{array}$ & $\begin{array}{c}|\mathrm{z}| \\
\text { value }\end{array}$ & $\mathrm{P}(>|\mathrm{z}|)$ \\
\hline Subtraction & 1.96 & 0.20 & 1.60 & 0.50 & 0.36 & 0.49 & 3.674 & $<0.001$ \\
\hline Induction & 1.80 & 1.19 & 2.64 & 1.19 & -0.84 & 1.46 & 2.871 & 0.002 \\
\hline Reliability & $4 \cdot 36$ & 1.15 & 3.52 & 1.47 & 0.84 & 1.84 & 2.281 & 0.011 \\
\hline Observation & 2.32 & 0.48 & 2.28 & 1.10 & 0.04 & 1.24 & 0.161 & 0.436 \\
\hline $\begin{array}{l}\text { Identification } \\
\text { Troubleshooting }\end{array}$ & 0.92 & 0.64 & 2.24 & 1.23 & -1.32 & 1.37 & 4.797 & $<0.001$ \\
\hline $\begin{array}{l}\text { experimental } \\
\text { group }\end{array}$ & $200 \mathrm{~s}$ & dents & & & & & & \\
\hline
\end{tabular}


The results for all five skills, subtraction, induction, reliability, observation, identification and troubleshooting, observed in Table 1, have a positive statistical significance. That is, after the intervention, all five students' critical thinking skills improved. control group.

Table 2 reflects the mean estimate and standard deviation for all five skills in the

Table 2. Measurement values of the factors of variables subtraction-induction-reliabilityobservation-problem identification and troubleshooting of the control group

\begin{tabular}{lcccccccc}
\hline & \multicolumn{2}{c}{ Before } & \multicolumn{2}{c}{ After } & & \multicolumn{2}{c}{ Result } \\
& $\begin{array}{l}\text { mean } \\
\text { estimate }\end{array}$ & $\begin{array}{c}\text { standard } \\
\text { deviation }\end{array}$ & $\begin{array}{c}\text { mean } \\
\text { estimate }\end{array}$ & $\begin{array}{c}\text { standard } \\
\text { deviation }\end{array}$ & $\begin{array}{c}\text { mean } \\
\text { estimate }\end{array}$ & $\begin{array}{c}\text { standard } \\
\text { deviation }\end{array}$ & $\begin{array}{c}\mathrm{z} \\
\text { value }\end{array}$ & $\mathrm{P}(>|\mathrm{z}|)$ \\
\hline Subtraction & 1.24 & 0.66 & 1.04 & 1.04 & 0.20 & 1.08 & 0.926 & 0.177 \\
\hline Induction & 2.52 & 1.32 & 2.28 & 2.28 & 0.24 & 1.54 & 0.782 & 0.217 \\
\hline Reliability & 3.84 & 1.17 & 3.40 & 3.40 & 0.44 & 1.68 & 1.305 & 0.096 \\
\hline Observation & 1.84 & 1.28 & 1.96 & 1.96 & -0.12 & 1.81 & - & 0.370 \\
\hline $\begin{array}{l}\text { Identification } \\
\text { Troubleshooting }\end{array}$ & 1.76 & 1.23 & 1.96 & 1.96 & -0.20 & 1.22 & - & 0.207 \\
\end{tabular}

control group 200 students

The results in Table 2 of the control group do not show statistical significance.

Summing up, the statistical analysis of the data surveyed provided evidence that the research hypothesis can be confirmed. In the classes where the students attended the theatrical workshops which were based on the principles of educational drama, the five skills were enhanced in contrast to the findings of the control group. Therefore, our experimental research revealed that the answer to the main research question is affirmative. Educational drama, as an innovative tool, can influence and enhance the critical thinking of primary school children.

At the same time, the data collected from the research diaries of the members of the research team was also interesting. In the first weeks, some students did not actively participate as the more dynamic ones took responsibility and guided the rest. It was observed that most groups had "leaders". In the process, however, even the weakest characters slowly began to express their opinions. Students began to trust and cooperate with each other. Through theatrical workshops, students were encouraged to take initiatives, to examine all the data of the problem, to listen to the opinions of others, to evaluate them and to be led to draw their own conclusions.

In the beginning, what was noted in the research diaries was that decision making by the students was often trivial. The students were not used to observing all the data, listening to the opinions of the others, as a result of which they made wrong decisions. In the process, however, and as the theatrical workshops progressed, their observation became sharper and to the point.

We were impressed that almost all of the students did not evaluate the source of the information at all, as a result of which they perceived incorrect information as correct. The fact is, however, that most students could assess a difficult situation, which could be solved by the hero of our story.

As for inductive and abstract thinking, which are skills that students have difficulty acquiring, it was observed towards the end of theatrical workshops, a fact that was not initially observed, students at the reflection stage could generalize their thinking. Students' phrases such as "since the hero is lying, the rest will be never led to the truth" were heard, or they had the ability 
A. Dima, E. Kaiafa \& A. Tsiaras - Evaluation of the Educational Drama as an Innovative Method...

to more easily formulate a series of interrelated sentences to prove the truth or not. They often recorded the details of the problem and drew their own conclusions.

Therefore, our experimental research revealed that educational drama, which is an innovative tool in the hands of teachers, can cultivate critical thinking skills.

\subsection{Discussion}

According to the results of the research, it turns out that educational drama, as an innovative method in educational practice, can cultivate the critical thinking skills of primary school students.

The educational drama approach focuses on experiencing and realizing reality. Through theatrical techniques, students experience and directly express their experiences, finding solutions to their problems (Adıgüzel, 2009). In students, pretending behavior, through roleplaying games, evolves from a complex of recreating experiences from their daily lives, stimuli from what they read, hear and see on television. This fact reflects their life experiences (Tsiaras, 2016b).

The aim, therefore, of the 15 experiential, theatrical workshops was for the students to master the dilemmatic situations in which the heroes found themselves and try to find the most suitable solutions. In order to be led to them, they had to sharpen their critical skills.

Students had to enhance their observation. We could achieve this with icy images or sculpture-sculpture technique. Students had to observe all the details in order to be able to draw a correct conclusion. Judging which of all the data is reliable to take into account in order to make the right decision, theatrical improvisations helped a lot to make this possible.

Role-playing games helped students learn to identify details and lead to generalization of results and thus enhance their inductive thinking. The ability of students to use their abstract thinking, that is, to find in a logical sequence way that could lead them to the most appropriate decision-making, was greatly helped by theatrical improvisations and the corridor of consciousness. Finally, all theatrical workshops closed with reflection. At the stage of reflection, the students became aware of the experience they lived through the educational drama.

The targeted planning of theatrical workshops was the appropriate factor in cultivating the skills of critical thinking and highlighting educational drama as an innovative tool in the hands of teachers.

\section{Conclusions}

Educational drama is a different educational proposal that essentially separates its position from the principles of traditional teaching and turns learning into an interesting and creative "game". Through this, students act independently, express their opinions freely, think critically, and act for the team. Educational drama, as an innovative tool for teachers, plays an important role in enhancing student's critical thinking because it can link thinking ability to behavior (Fisher, 2008: 164).

We wanted to take advantage of this innovative proposal and prove in essence that primary school students, in a pleasant environment, can enhance their critical thinking skills. Specifically, the skills studied and measured were observation, subtraction, induction, reliability, detection and troubleshooting. The results of the research proved that educational drama has a positive effect on this advanced type of thinking. 
Given the fact that the scope of research on critical thinking combined with educational drama is limited and the issues under consideration, we believe that the implementation and proof of the goals we set from the beginning, to cultivate critical thinking in primary school students, will re-position in a positive direction the important role of education in Greece, for the benefit of our society.

\section{Acknowledgements}

This research is co-financed by Greece and the European Union (European Social Fund - ESF) through the Operational Programme "Human Resources Development, Education and Lifelong Learning 2014-2020", in the context of the project "Empowerment of Critical Thinking skills through Drama in Education in primary's schools students” (MIS 5048964).

The authors declare no competing interests.

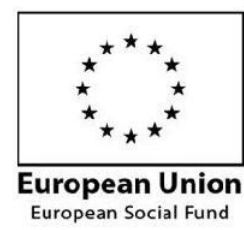

References

\author{
Operational Programme \\ Human Resources Development, \\ Education and Lifelong Learning \\ Co-financed by Greece and the European Union
}

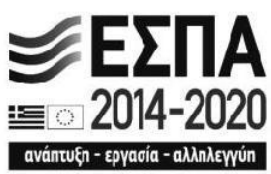

Adıgüzel, H. O. (2009). The past and present in drama education in the Turkish Educational System: Issues and challenges. In N. Gkovas (Ed.), Theater and education in the center of the stage (pp. 8393). Athens: PanHellenic Club for Theatre in Education.

Anderson, M. (2012). Masterclass in drama education (1 $1^{\text {st }}$ Ed.). London: Continuum International Pub. Group.

Bailin, S. (1998). Critical thinking and drama education. Research in Drama Education: The Journal of Applied Theatre and Performance, 3(2), 145-153. https://doi.org/10.1080/1356978980030202

Bailin, S., Case, R., Coombs, J., \& Daniels, L. (1999). Common misconceptions of critical thinking. Journal of Curriculum Studies, 31(3), 269-283. https://doi.org/10.1080/002202799183124

Boal, A., Leal-McBride, M., Leal McBride, C., \& Fryer, E. (2008). Theatre of the oppressed. London, UK: Pluto Press.

Bolton, G. (2007). A history of drama education: A search for substance. International Handbook of Research in Arts Education, 16, 45-66. https://doi.org/10.1007/978-1-4020-3052-9 4

Burgess, D. (1981). A spectrum of achievements. Nature, 294(5837), 111-112. https://doi.org/10.1038/294111ao

Cattanach, A. (1996): Performance studies: An introduction. London: Routledge.

Ennis, R. (1989). Critical thinking and subject specificity: Clarification and needed research. Educational Researcher, 18(3), 4-10. https://doi.org/10.3102/0013189x01800300410.1007/s11245-0169401-4

Ennis, R. (2018). Critical thinking across the curriculum: A vision. Topoi, 37(1), 165-184.

Ennis, R.H., Gardiner, W. L., Morrow, R., Paulus, D. \& Ringel, L. (1964). Cornell class reasoning test. University of Illinois: Champaign, IL.

Facione, N., \& Facione, P. (1996). Externalizing the critical thinking in knowledge development and clinical judgment. Nursing Outlook, 44(3), 129-136. https://doi.org/10.1016/s0029-6554(06)800059 
A. Dima, E. Kaiafa \& A. Tsiaras - Evaluation of the Educational Drama as an Innovative Method...

Facione, P., \& Facione, N. (2013). Critical thinking for life. Inquiry: Critical Thinking Across the Disciplines, 28(1), 5-25. https://doi.org/10.5840/inquiryct20132812

Finlay Johnson, H. (1911). The dramatic method of teaching (1 ${ }^{\text {st }}$ Ed.). London: James Nisbet and Co.

Fisher, A. (2008). Critical thinking: An introduction. Cambridge: Cambridge University Press.

Heathcote, D. (1984) The authentic teacher and the future. In L. Johnson \& C. O' Neill (1984) (Eds.), Dorothy Heathcote: Collected writings on drama and education (pp. 170-199). London: Hutchinson.

Huss, R. (2019). Preparing teachers for the $21^{\text {st }}$ century classroom. Internet Learning, $7(1)$. https://doi.org/10.18278/il.7.1.3

Jörissen, B., Unterberg, L., Klepacki, L., Engel, J., Flasche, V., \& Klepacki, T. (2018). Spectra of Transformation ( $1^{\text {st }}$ Ed.). Munster-New York: Waxmann.

Kalidas, C. (2013). Drama: A tool for learning. Procedia - Social and Behavioral Sciences, 123(123), 444449. https://doi.org/10.1016/j.sbspro.2014.01.1443

Kamens, D., \& Cha, Y. (1992). The legitimation of new subjects in mass schooling: 19th-century origins and $20^{\text {th }}$ century diffusion of art and physical education. Journal of Curriculum Studies, 24(1), 436o. https://doi.org/10.1080/0022027920240103

Kennedy, M., Fisher, M. B., \& Ennis, R. H. (1991). Critical thinking: Literature review and needed research. In L. Idol \& B. F. Jones (Eds.), Educational values and cognitive instruction: Implications for reform (pp. 11-40). Hillsdale, New Jersey: Lawrence Erlbaum \& Associates.

Kerlinger, F. (1979). Foundations of behavioral research. New York: Holt, Rinegart.

Kolaczyk, E. D. (2009). Statistical analysis of network data: Methods and models. New York: Springer.

Kuhn, D. (2019). Critical thinking as discourse. Human Development, 62(3), 146-164. https://doi.org/10.1159/000500171

Landy, R., \& Montgomery, D. (2012). Theatre for change. Basingstoke: Palgrave Macmillan.

Marin, L., \& Halpern, D. (2011). Pedagogy for developing critical thinking in adolescents: Explicit instruction produces greatest gains. Thinking Skills and Creativity, 6(1), 1-13. https://doi.org/10.1016/j.tsc.2010.08.002

Mc Peck, J. (1981). Critical thinking and education. New-York: St Martin's Press.

Neelands, J. (2011). Editorial. English in Education, 45(1), 1-5. https://doi.org/10.1111/j.17548845.2010.01089.X

Pavis, P., \& Ubersfeld, A. (2006). Dictionnaire du théâtre (1 $1^{\text {st }}$ Ed.). Paris: Dunod.

Prentki, T., \& Stinson, M. (2016). Relational pedagogy and the drama curriculum. Research in Drama Education: The Journal of Applied Theatre and Performance, 21(1), 1-12. https://doi.org/10.1080/13569783.2015.1127153

Schmaltz, R., Jansen, E., \& Wenckowski, N. (2017). Redefining critical thinking: Teaching students to think like scientists. Frontiers in Psychology, 8, 459. https://doi.org/10.3389/fpsyg.2017.00459

Scriven, M. (1987). Critical thinking and the concept of literacy. Informal Logic, 9(2), 94-110. https://doi.org/10.22329/il.vgi2.2665

Sextou, P. (2004). Drama and theatre education: a proposal for the establishment of Hellenic theatre in education (TiE); possibilities and problems in developing aspects of the British TiE expierence in Greece towards the provision of professional theatre with an educational purpose in preschool and primary education. Ph.D Thesis, Goldsmith College University of London.

Starkey, L. (2010). Critical thinking skills success in 20 minutes a day. New York: Learning Express.

Tsiaras, A. (2016a). Enhancing school-aged children's social competence through educational drama. The Journal of Drama and Theatre Education in Asia, 6(1), 65-90. 
Tsiaras, A. (2016b). Improving peer relations through dramatic play in primary school pupils. International Journal of Education \& the Arts, 17(18), 1-21.

Varriour, P. (1994). In role: Teaching and learning dramatically. Ontario: Pippin Publishing.

Winship, F. (1954). Educational theatre: A definition. The Southern Speech Journal, 19(4), 317-323. https://doi.org/10.1080/10417945409371327 
A. Dima, E. Kaiafa \& A. Tsiaras - Evaluation of the Educational Drama as an Innovative Method...

C O A $\mathbf{s}$ 